\title{
PEMAHAMAN METODOLOGI DALAM NEW LIFE MOVEMENT TEORI IDE OPEN SOCIETY
}

\author{
Ali Imron*
}

\section{Pendahuluan}

Suatu dinamika pengetahuan, substansinya terawali oleh sebuah proses panjang. Idealitasnya hasil research merupakan serangkaian produk pengetahuan yang dapat sekaligus mampu digunakan sebagai sebuah teori dan metodologi dalam desain pengetahuan. Relatifitasnya apakah sebatas teori ataukah mampu terbreak down hingga implementasi dan aktualisasinya sekaligus dimungkinkan untuk mewujud menjadi common theory.

Metodologi penelitian yang coba penulis gunakan adalah metodologi penelitian: positivisme ${ }^{1}$, rasionalisme ${ }^{2}$, phenomenology ${ }^{3}$, dan teori ilmu realisme ${ }^{4}$

\footnotetext{
* Institut Agama Islam Tribakti (IAIT) Kediri

${ }^{1}$ Metodologi positivisme di sini yang dimaksud adalah positivisme antologik, realitas dapat dipecah-pecah, dapat dipelajari independen, dieliminasikan dari obyek yang lain, dan dapat dikontrol.Karena itu, salah satu konsekuensi yang paling mendasar dalam metodologi penelitiannya adalah kerangka teori dirumuskan sespesifik mungkin dan menolak suatu ulasan meluas yang tidak langsung relevan dan dari sisi epistemologik positivismenya menuntut pilahnya subyek peneliti dengan obyek peneliti (termasuk subyek pendukungnya). Maksud memilahkan subyek dari obyek agar dapat diperoleh hasil yang obyektif. Tujuan riset yang berlandaskan metodologi ini adalah menyusun bangunan ilmu nomothetik, yaitu ilmu yang berupaya membuat hukum dari generalisasinya. Kebenaran dicari lewat hubungan kausal-linier tiada akibat tanpa sebab dan tiada sebab tanpa akibat.Teori kebenaran yang dianut dalam metodologi positivisme adalah termasuk teori korespondensi. Sesuatu itu benar apabila ada korespondensi atau ishomorphism antara pernyataan verbal atau matematik dengan realitas empirik (yang dalam positivisme dibatasi pada empiri sensual/indrawi). Dan juga ditinjau dari segi aksiologik positivisme menuntut agar riset itu bebas nilai (value free) mereka mengejar obyektivitas agar dapat ditampilkan prediksi atau hukum yang keberlakuannya bebas waktu dan tempat. Lihat Noeng Muhajir, Metodologi Penelitian Kualitatif, Ed. III (Jogjakarta: Rake Sarasin,1996), h. 9.
} 


\section{Pengertian Open Society Dalam New Life Movement}

Bangsa modern adalah sifat dari perbedaan golongan yang mencakup relationship, seperti contoh relationship church and state. Kemodernan adalah merupakan produk dari perbedaan sejarah dan struktur sosial. ${ }^{5}$ Open society dalam language interpretation diambil dari idiom Inggris yang berarti masyarakat terbuka. ${ }^{6}$

\section{Striving Open Society Dalam Aksi Sosial}

Seperti yang terjadi dalam berbagai revolusi sosial, baik di Italia, Inggris, Prancis, Jerman, Rusia, Iran, Iraq, Afghanistan, India, Israel, Amerika, Nicaragua, Colombia, Bolivia, Argentina, Chili, Paraguay, Brasilia, Elsavador, Pakistan, Malaysia, Korea, Palestina, Syiria, Indonesia, Mesir dan bahkan

${ }^{2}$ Rasionalisme di sini yang dimaksud adalah Ilmu yang tingkat validitasnya didasarkan atas abstraksi, simplifikasi atau idealisasi dari realitas dan terbukti koheren dengan sistem logikanya. Lihat Ibid., h.11

${ }^{3}$ Metodologi phenomenology di sini hampir sejalan dengan rasionalisme, yaitu melihat obyek dalam konteksnya dan menggunakan tata pikir logis dan lebih dari sekadar linier kausal. Selain itu, maksudnya adalah penelitian kualitatif yang menyangkut grounded research (sosiologi), etnometodologi (antropologi), paradigma naturalistik (hitungan matematis), interaksi simbolik, heuristik, hermeneutik, atau holistik. Dan selanjutnya, dalam memperoleh kebenaran dalam menemukan kebenaran empirik melalui metodologi fenomenologi ini ada empat hal, yaitu: 1). kebenaran empirik sensual, 2). kebenaran empirik logik, 3). kebenaran empirik etik, 4). kebenaran empirik trensendental. Lihat Ibid. h. 12-13.

${ }^{4}$ Teori ilmu realisme di sini memiliki maksud bahwa ilmu itu sendiri memiliki arti untuk membangun sistem ide-ide tentang semesta sebagai realitas. Dan menyangkut realismenya dalam epistemologinya sejalan dengan rasionalisme dan positivisme, yaitu nomothetic. Dan sebenarnya berlawanan dengan fenomenologi yang idiografik. Dan perbedaan di situ menurut Feyerabend dimaknai sebagai keragaman sedangkan hal esensialnya sama dan tampil sebagai keajegan dalam keragaman. Tegas-tegas realisme menekankan fungsi ilmu, yaitu mengembangkan tesis, hukum, prinsip, yang dapat dipakai untuk membuat inferensi atau ramalan yang berlaku dalam ragam ruang dan waktu. Lihat, Ibid. h., 13-15.

${ }^{5}$ J. Milton Yinger, The Scientific Study of Religion, (New York :Macmillan Publishing, 1970), h. 431.

${ }^{6}$ Karl R. Popper, The Open Society and Its Enemies, (New Jersey : Princeton Univercity Press, 1950), h. 214. 
dunia, sebenarnya memiliki akar persoalan yang hampir sama yaitu tuntutan masyarakat karena akibat;

a. Belum terciptanya paradigma dan pandangan hidup setiap individu secara fair dan terbuka bagi sosial civilization dalam menumbuhkan semangat kebersamaan masyarakat dunia theory of everithing,

b. Belum sesuainya sistem dan tatanan sosial bagi masyarakat secara global, dalam arti masih adanya klas sebagai dimensi pelapisan sosial (piecemeal social enginering) atau (utopian social enginering),

c. Kurangnya komunikasi terbuka antar kelompok sosial (less communication) atau kurangnya sosialisasi rasa keterbukaan antar sesama (closed solidarity) dan masih tersimpanya rasa ingin saling monopoli dan menguasai antara kelompok (cluster) dan individu yang satu dengan yang lain,

d. Masih banyaknya kepentingan political grouping dan human ephemeral construct,

e. Pertarungan hegemoni dalam hal ekonomi, politik, sosial, budaya, agama, etika, adat istiadat, bahasa, ilmu pengetahuan, pendidikan, karya, cipta, karsa dan bahkan peradaban yang cukup kuat dengan sponsor fanatisme masing-masing wilayah serta agama.

Masalah-masalah tentang striving open society disinergikan dengan teori sosial civilization dalam sejarah humanism. Berbagai kalangan seperti halnya Mircea Eliade, ${ }^{7}$ Wilfred Cantwell Smith, ${ }^{8}$ Joseph M. Kitagawa, ${ }^{9}$ Ninian

${ }^{7}$ Mircea Eliade adalah orang yang berkelahiran di Bukharest, Rumania, tahun 1907, dan dirinya pernah menjadi staf pengajar universitas Bukharest dan Ecole des Hautes Etudes, di Sorbonne, Paris dan juga termasuk anggota tetap dari pertemuan tahunan perkuliahan Eranos di Ascona, Swiss. Berbagai macam pemikiranya dapat dibaca dalam karyakaryanya yang terkenal diantaranya The Myth of the Eternal Return (Myth and History), The Cacred and the Profane, Patterns in Comparative Religion, Birth and Rebirth, dan Yoga-Imortality ang Freedom, The two and the one, the Quest, dan A History of Religious ideas. Untuk lebih jauh baca Bukunya M. Eliade dan Joseph M. Kitagawa, The History of Religions, Essays on Metodology, (Chicago: Univercity of Chicago Press, 1974).

${ }^{8}$ Wilfread cantwel smith adalah orang yang berkelahiran di Toronto, Kanada tahun 1916, dan dirinya adalah seorang professor Ilmu perbandingan agama sekaligus pernah menjadi direktur institut of Islamic 
Smart, ${ }^{10}$ mereka semua mencoba memadukan desain identitas diri dalam kronologi dan orientasi disiplin ilmu guna membangun dialog yang dialogis, serta lebih jauh bagaimana dalam konteks dasar open society dapat digunakan sebagai persiapan kerjasama antaragama, masyarakat dan negara.

\section{Struktur Ide Open Society dalam Studi Simbolis}

Obyek dan aplikasi studi dalam struktur fenomenologi dan metodologi serta studi simbolism seperti yang diungkap oleh Rafaele Pettazoni, Mircea eliade, Raimundo Pannikar, ${ }^{11}$ Friedrich Heiler, ${ }^{12}$ Joachim Wach, Ursula King

Studies di McGill Univercity, Montreal, Kanada. Berbagai macam pemikirannya banyak dipengaruhi karena akibat proses pendidikan yang dialaminya di WestminsterCollege, Cambridge, jurusan teologi. Gelar doktoralnya diperoleh dalam kajian dunia timur (oriental studies) di princeton Univercity. Dirinya termasuk staf pengajar di FormanChristianCollege, Lahore, India, dalam bidang studi sejarah islam dan sejarah india. Berbagai macam pemikiranya dapat dibaca dalam bukunya M. Eliade dan Joseph M. Kitagawa, The history of Religions, h . $31-58$.

${ }^{9}$ Joseph M. Kitagawa adalah orang yang dilahirkan di Osaka, Jepang, pada tahun tahun 1915. Dirinya termasuk pernah menjadi staf pengajar sejarah agama-agama di universitas of chicago dan juga sebagai konsultan Encyclopedia Britanica. Dirinya juga pernah sempat ,mengajar di jurusan kajian budhis di koyasan univercity, jepang. Sebenarnya dirinya memiliki cukup banyak karya, akan tetapi yang terkenal adalah hasil editan yang dilakukan bersama dengan Mercia Eliade yang berjudul The history of Religions (Essays in Methodology), (Chicago: The Univercity of Chicago Press, 1974).

${ }^{10}$ Ninian Smart adalah termasuk salah satu staf pengajar di Univercity of California at Santa Barbara, dan Univercity of Lancaster, dimana dirinya mendirikan jurusan Religious Studies yang pertama di Inggris. Ia juga Staf pengajar di Univercity of Wales, Uniovercity of London King's of College. Profesor teologi di univercity Birmingham, dan professor tamu untuk sejarah agama-agama di universitas Princeton, Wiscounsin, Otago dan Queensland. Dan berbagai macam pemikiranya dapat dibaca dalam karya-karyanya Reason and Faith, Doctrine and argumentation in indian philosophy, The henomenon of religion, the science of religion and the sociology of knowledge, Beyond Ideology. Dan untuk keterangan lebih jauh baca buku Ninian Smart, The Science of Religion and the Sociology of The Knowledge, (Princeton: Princeton Univercity Press, 1973).

${ }^{11}$ Raimundo Pannikar adalah seseorang yang dilahirkan di Barcelona, Spanyol tahun 1918. Dirinya tercatat sebagai warga negara India, sebagai orang yang hidup didalam dua tradisi agama besar Katolik dan 
Jacques Waardenburgh, Frank Whaling, yang sebenarnya kesemua dari mereka mencoba memadukan dan menformulasikan berbagai kajian sosial dan agama dalam konteks humanitas global untuk menjawab berbagai pertanyaan, yang diantaranya; dapatkah obyek dan aplikasi sejarah mampu menjawab pergulatan debat metodologis dalam konteks global

Hindu. Dirinya sudah tertarik pada persoalan pluralisme agama-agama sejak usia muda. Ia belajar sains di Bonn, Jerman dan Barcelona, bahkan meraih doktor ilmu kimia di universitas madrid, sementara doktor untuk bidang filsafat telah ia raih dari universitas yang sama sejak 1946, dan gelar doktor teologi dari universitas Roma tahun 1961. Ia menghabiskan separoh hidupnya di Eropa,seperempatnya di India, dan seperempat yang lain di Amerika Serikat, meskipun tetap menjalin hubungan erat dengan orang eropa dan menghabiskan waktu beberapa bulan tiap tahunya di india. Jabatan terakhirnya adalah professor religious studies (filasafat agama perbandingan dan sejarah agama-agama) di universitas of California at santa barbara. Sepanjang hidupnya Raimundo Pannikar telah mengajar tidak kurang di 100 unioversitas diseluruh dunia, telah menulis tidak kurang dari 300 artikel dengan tema sangat luas, mulai dari filsafat ilmu hingga metafisika, dari perbandingan agama hingga indologi, dan diantara 28 buku yang telah ditulisnya The unknown christ of hinduism, Worship and secular man, the trinity and the religious Experience of man, the vedic Experience : Mantramanjari, an Anthologi of the Vedas for modern man, intralegious dialogue, myth faith and hermeneutics, dan Blassed implicity : the monk as universal archetype. Untuk keterangan dan penjelasan lebih jauh baca bukunya Jacques Waardenburgh, The dialogical dialogue, The worldreligious traditions, current perpectives in religious studies, essays in honour of wilfred cantwell smith,( Edinburh : T\&T Clarak Ltd, 1984).

${ }^{12}$ Friedrich Heiler adalah seseorang yang dilahirkan dikota munich , Jerman, tahun 1892. Dirinya meraih Ph.D di universitas Munich Th.D (honoris) dari universitas kiel, dan D.D. dari universitas glasgow. Ia menjabat sebagai professor untuk bidang sejarah agama-agama di universitas marburg sejak 1920 sekaligus presiden IAHR cabang Jerman. Dirinya juga menjabat sebagai presiden persatuan ekumeni-Injili Jerman, direktur religions kunliche summlung di universitar marburg serta wakil presiden untuk kongres iman dunia (word Congress of Faith) cabang Jerman. Ia sempat memberikan kuliah Heskel di Universitas Chicago tahun 1955. Dan pemikiranya dapat dibaca dalam karya-karyanya yang terkenal diantaranya Prayer (das gebet), Budhiistiche Versenkung, Die Mystik der upanishaden, sadhu sundar singh, Der Katholozismus, urkirche und ostkirche,Altkirchli- cheautonomie und papstliche zentralismus, serta Die religionen der menscheit in vergenggenheit und gegentwart. 
pasca perang dunia II, ${ }^{13}$ atau bahkan mungkin dapatkah obyek dan aplikasi sejarah mampu mewujudkan sistem kekinian tentang teori relationship dan demeanor serta behavior antarumat seagama dan tidak seagama menuju sebuah nation building, construst society building, collective bargainning, branch of science ability charitable and practice, conaction humanity, development of mentality, behavior and solidarity society, nation and state yang kemudian disebut dengan open society.

Serta mampukah memunculkan sederetan teori open society dalam membangun masyarakat tanpa perbedaan tanah air, warna kulit, bahasa, agama, adat istiadat dan kebudayaan, sehingga dapat digunakan sebagai common theory dan unvil of life dalam membina dan meningkatkan serta menjunjung tinggi nilai-nilai religiousness, branch of science ability, social humanity, togetherness dan verdict serta human right dalam bersikap, berkreasi dan berbudaya menuju masyarakat terbuka (open society).

\section{Sinergisitas Ide Open Society Dengan Social Civilization}

Bahasan open society yang menjadi pokok pembahasan, kepatutan orientasi metodologi disinergikan dengan teori sosial civilization dalam sejarah humanism. Gambaran gerakan humanis Italia yang memiliki karakter totalitarianism, dianggap mampu memberikan inspirasi atas munculnya renaissance eropa, termasuk Inggris, Prancis dan Jerman. ${ }^{14}$

Proses civilization yang berawal dari abad ke 14 sampai abad ke 18 hingga muncul zaman pencerahan (aufklarung) tersebut menghasilkan teori dan metodologi keilmuan, sosial, hubungan kemasyarakatan, keagamaan, kebangsaan dan ketatanegaraan. Di antara yang termasuk founding fathers gerakan humanism adalah diantaranya Nikolaus Kopernikus, Johanes Kepler, Galileo galilei, Hugo de Groot, Niccolo

${ }^{13}$ Ahmad Norma Permata, Metodologi Studi Agama, (Jogjakarta: Pustaka Pelajar, 2000), h. $61-544$.

${ }^{14}$ Harun Hadi Wijono, Sari Sejarah Filsafat Barat, h. 11 - 17. 
Nachiavelli, Thomas More, Francis Bacon dan lain sebagainya. ${ }^{15}$

Walaupun semangat perlawanan terhadap diskriminasi dan monopoli sudah ada sejak zaman Heraclitus, Phitagoras, Plato dan Aristoteles.Doktrin semangat perlawanan terhadap penindasan sosial, seperti zaman Hegel dan Mark banyak yang digunakan sebagai sandaran ilmu pengetahuan dan aksi sosial. Termasuk juga society civilization dalam sejarah renaissance sampai aufklarung hingga filsafat modern konstruksi teori dan metodologi kesejarahanya sampai sekarang masih digunakan sebagai dasar dan prinsip konstruksi sosial demokrat untuk menentukan rumusan nilai dan persepsi dalam keilmuan dan fungsionalnya.

\section{Rasionalitas Argumentasi Open Society}

Argumentasi-argumentasi open society yang terlihat cukup rasional dari sisi teori dan metodologi dalam urgensinya masih diadopsi sebagai pengalaman sejarah berupa acuan general research masyarakat terdahulu, diantaranya teori dan metodologi phenomenologi, positivisme, realisme, dan rasionalisme.

Analisa sistematik terhadap realitas historis, teori dan metodologi yang dihasilkan ternyata masih laku dari sisi fungsionalnya di kalangan peneliti dan pemerhati sosial, agama, bangsa dan negara. ${ }^{17}$ Kerangka teori dan metodologi bahasan open society ini menggunakan teori dan metodologi yang ada persesuaian dengan pengalaman real, rasional dan empirik, termasuk diantaranya proses mutualisme simbiosis civilization, sikap dan budaya manusia yang terjadi pada saat muncul dan berkembangnya tuntutan konsep-konsep sosial, filsafat, keagamaan, kemasyarakatan, kebangsaan dan ketatanegaraan pada zaman awal abad ke 14 hingga sekarang.

Seperti asumsi yang dikatakan oleh Thomas Luckman yang mengatakan bahwa pemanandangan dunia adalah sebuah sistem pertengahan (antara ujung yang ekstrim) yang

\footnotetext{
${ }^{15}$ Ibid.

${ }^{16}$ Noeng Muhajir, Metodologi Penelitian Kualitatif, Ed III, h. 9 - 15

${ }^{17}$ Ibid.
} 
didalamnya mencakup kategori relevansi sosial dalam bentuk waktu, tempat, sebab musabab, dan maksud atau tujuan. ${ }^{18}$

Tidak bisa dipungkiri bahwa sekarang ini masih ada semangat dan benih-benih pemberontakan terhadap peradaban manusia karena masih adanya diskriminasi dan semangat monopoli serta sekaligus perongrongan dan propaganda terhadap hak azasi manusia sebagai makhluk yang bebas, merdeka, dan berbudaya.

Termasuk diantaranya munculnya tokoh seperi F.D.E.Schleiermacher, Wilhelm Dilthey, Hans- Georg Gadamer, Jurgen Habermas, Paul Ricoeur, Jacques Derrida, yang kemudian melalui produktifitas rasional kesejarahan ada konsep diachronic yang disebut open minded. ${ }^{19}$ Walaupun dalam tataran aktualisasi realitasnya terjadi dalam komunitas yang berbeda.

\section{Open Society Memiliki Akar Sejarah}

Bahasan open society mengunakan pendekatan analisa ilmu kesejarahan, baik itu agama, budaya, filsafat, sosiologi, fenomenologi, antropologi, visiologi maupun konsepsi yang telah terbuku dan terbakukan oleh para pakar sejarah, serta ilmu metodologi dan teori yang telah ada.

Premis-premis open society secara definitip, para pemikir memberikan berbagai macam definisi dengan latar belakang yang berbeda beda. Akan tetapi secara keseluruhan baik itu secara etimologi maupun terminologi dapat kita sepakati sebagai berikut, secara etimologi, dalam bahasa Inggris open memiliki arti yang fariatip yaitu terbuka, bebas, buka, terangterangan (in attitude), berlubang-lubang (texture), lepas, terluang. $^{20}$

Akan tetapi definisi secara meaning selection disini dapat kita tarik penggunaan katanya secara benar dengan menggunakan landasan ungkapan open yang dilanjutkan dengan terusan katanya yaitu society.Para tokoh, diantaranya menurut

${ }^{18}$ Andrew M. Greeley, Sociology and Religion, A Collection of Readings, (New York: Univercity of Chicago, 1995), h. 220.

${ }^{19}$ E. Sumaryono, Hermeneutik, sebuah metode Filsafat, Ed. Revisi, (Jogjakarta: Kanisius, 1999)

${ }^{20}$ John M. Echols dan Hassan Sadily, Kamus Inggris Indonesia, An English - Indonesian Dictionary, h. 405 - 406. 
Karl R. Popper open berarti terbuka, dan meaning yang tersimpan didalam kata itu adalah meaning humanity dalam bentuk aksi sosial. ${ }^{21}$ Menurut George Soros untuk meaning kata ini di titik beratkan dalam dimensi komitmen ethics, communication dan belief, dengan bukti bahwa dirinya mendirikan open society institute serta melakukan beragaman kegiatan filantropis. ${ }^{22}$

\section{Importensi Kaukus Ulang Paradigma Open Society}

Dalam bahasa inggris, masyarakat disebut society, asal katanya socius yang berarti kawan. Ada pun kata masyarakat berasal dari bahasa Arab, yaitu syirk, artinya bergaul. ${ }^{23}$

Penterjemahan terhadap kata, bahasa atau ungkapan baik secara etimologi maupun terminologi, sebenarnya harus mengikuti ritme dan meaning word dalam fungsionalnya, terutama menyangkut sebuah tatanan sosial yang kompleksitasnya perlu diterjemahkan melalui teori dan metodologi.

Termasuk bahasan open society yang menyangkut dengan realitas sosial empirik masyarakat Indonesia dalam pluralitas dan perbedaan-perbedaanya. Sedangkan open society menurut terminologi adalah masyarakat yang dalam komunitasnya tidak lagi mempedulikan (acuh) serta mempersoalkan terhadap adanya perbedaan tanah air, agama, suku, bahasa, warna kulit, budaya, adat istiadat dan memiliki cita-cita terbuka dalam masyarakatnya.

Cita-cita itu adalah untuk membentuk sebuah nation building, construst society building, collective bargainning, branch of science ability charitable and practice, conaction humanity, development of mentality, behavior and solidarity society, nation and state.

Begitu juga sepeti yang dikatakan oleh Henry Bergson dalam bukunya Two Sources of Morality and Religion bahwa

${ }^{21}$ Karl. R. Popper. Open Society and Its Enemies, h. 215.

${ }^{22}$ Agus Maulana, George Soros, Soros tentang soros, (Jakarta: Professional Book, 1997)

${ }^{23}$ M.Munandar Sulaiman, Ilmu Sosial Dasar, Teori dan Konsep Ilmu Sosial, Ed. Revisi, (Bandung: Refika Aditama, 1998), h. 63. 
masyarakat terbuka adalah masyarakat religius dan kritis serta mendasarkan setiap keputusan mereka berdasarkan intelejensi mereka sendiri dengan didasari etika religi. ${ }^{24}$

\section{Paradigma Pembebasan Ide Open Society}

Secara epistemologi dan hermeunetika empirik, paradigma pembebasan ternyata satu hal yang juga ikut mengilhami atas munculnya open society, ini terbukti dengan empat sumber nilai yang melalui sumber hermeneutika yang berbeda kadar dan intensitasnya dapat mengkonstruksi kedalam empat pilar paradigma pembebasan yang berhubungan dengan nilai-nilai open societydiantaranya :

1. Kemerdekaan (independency) yang kita mengerti tidak hanya sekedar otonomi atau kemerdekaan wilayah, tetapi terlebih adalah kemandirian manusia/ rakyat sebagai hasil karya penciptaan Allah yang tinggi.

2. Kesaudaraan (solidarity), bukan persaudaraan, sebab kesaudaraan adalah sesuatu yang harus diusahakan dari kedua belah atau beberapa belah pihak. Artinya bukan sekedar brotherhood (persaudaraan atau kekeluargaan), terlebih adalah rasa hormat terhadap pribadi lain dengan segala keunikan dan kemajemukanya.

3. Keadilan sosial (social justice) artinya bukan sekedar persamarataan (equality) tetapi terlebih adalah pencukupan syarat/ sarana dasar kehidupan bagi semua.

4. Kerakyatan (populist), tetapi terlebih adalah cinta kepada kemanusiaan, terlebih mereka yang masih dipinggirkan. ${ }^{25}$

Kepentingan teknis dalam landasan teori disini, juga sebagai tanda masyarakat modern yang juga membicarakan tentang implikasi-implikasi keagamaan dari ilmu dan pengalaman sosial sebuah frase yang mengandung sejumlah eksistensi yang disengaja atau tidak.Akan tetapi semuanya didasari atas dua hal yaitu ilmu dan pengamalan sosial.

${ }^{24}$ Henry Bergson, Two Sources of Morality and Religion, (Inggris; tp. 1935), h. 229.

${ }^{25}$ Francis Wahono Nitiprawiro, Teologi Pembebasan, Sejarah, Metode, Praksis, dan Isinya, (Jogjakarta : LkiS, 2000), h. xxix. 
Hal itu mengisyaratkan bahwa ilmu dan pengalaman sosial tidak hanya memiliki implikasi-implikasi terhadap agama, bangsa dan negara, akan tetapi juga memiliki implikasiimplikasi atau aspek-aspek lain dalam bentuk sikap atau interaksi antar sesama baik atas dasar motifasi agama, budaya, adat istiadat, ras, politik dan lain sebagainya. Bahkan hal yang dilatar belakangi realitas semacam itu dapat memunculkan konflik apabila dalam aplikasinya tidak mempu memberikan keseimbangan dalam menemukan teori interaksi dalam fenomena yang ada dalam sebuah komunitas masyarakat.

\section{Problem Empirik Agama - Sosial dalam Open Society}

Asumsi logika sempit bahwasanya hubungan dan sikap antaragama dan sosial merupakan hubungan yang rumit.Dan dalam beberapa segi bersifat organis. Hal ini secara sadar berbeda dari pandangan sekularisasi, yaitu pandangan yang melihat bahwa hanya terdapat hubungan yang mekanis antara pengetahuan, agama dan sosial yakni semakin banyak yang satu semakin sedikit yang lain.

Berkembangnya ilmu pengetahuan dalam dunia modern serta sikap keagamaan dan hubungan sosial dengan agama dapat mengakibatkan kemunduran secara terus menerus, apakah itu agamanya atau pemeluknya apabila tidak diimbangi dengan kesiapan perangkat penyeimbangnya.

Dari uraian diatas konklusi problematika empirik agama sosial, kemudian memunculkan tiga tipe utama kajian sosiologi agama yang dilakukan oleh para pakar sosiolog, yang diantaranya:

1. Mereka mengakaji agama sebagai sebuah persoalan teoretis yang utama dalam upaya memahami tindakan sosial dan sikap keagamaan.

2. Mereka menelaah kaitan anataragama dan berbagai wilayah kehidupan sosial lainya, seperti ekonomi, politik, dan kelas sosial dalam kepentingan-kepentingan tertentu.

3. Mereka mempelajari peran organisasi dan gerakan-gerakan keagamaan termasuk tokoh dan keilmuan yang membimbing dan mengarahkanya.

\section{Penanaman Ideologisasi Wacana Ide Open Society}


Konteks lain dalam penekanan narasi pengertian open society baik secara etimologi maupun terminologi ada yang mengatakan bahwasanya secara etimologi kata ini merupakan dua rangkaian kata yang mewujud menjadi satu yang kemudian memunculkan meaning yang berhubungan dengan doktrin sosial yaitu open berati terbuka ${ }^{26}$ dan society berati masyarakat ${ }^{27}$ jadi devinisi secara etimologi integral adalah masyarakat terbuka. ${ }^{28}$

Adapun devinisi lain menurut terminologi adalah masyarakat terbuka yang memiliki hubungan dengan realitas individu, sosial, kemanusiaan dan kemasyarakatan yang terbingkai dengan semangat persatuan. ${ }^{29}$ Selain itu open society menurut Walter Lippman dan Graham Wallas dalam bukunya The Good Society ada hubunganya dengan reaksi masyarakat rasionalis karena akibat kemandegan dan ketertutupan sistem sosial. $^{30}$

Dalam berbagai teori sosial banyak dari sekian kalangan sosialis memberikan berbagai konsep disiplin ilmu yang muncul dari produk sejarah empirik yang memiliki latar belakang dan ruang lingkup yang berbeda-beda.Seperti yang diungkap oleh Thoules tentang konflik moral yang ada dalam masyarakat, ketika terkait dengan psikilogi sosial dan individu dalam keragamanya. $^{31}$

Selain hal diatas ketika kita mempelajari teori sosial yang dimunculkan sekitar tahun 1500 - 1600 an, dengan teori dan konsep rasionalisme, realisme, skeptisisme-nya Rene Descartes, Baruch Spinoza yang memunculkan teori karakter dengan memunculkan konsep tentang kehendak dan kekuatan serta dualisme dalam prosesi kesadaranya.yang mulai saat itu

\footnotetext{
${ }^{26}$ Jonhn M.Echols dan Hasan Shadily, Kamus Inggris Indonesia ,h.405

${ }^{27}$ Nur Akhmad, Pluralitas Agama, Kerukunan dalam keragaman, (Jakarta : Kompas, 2001), h. 14.

${ }^{28}$ Untuk bahasan yang lebih detail dan lebih jauh baca dalam bukunya Karl.R.Popper, The Open Society and Its Enemies, h.209 - 250.

${ }^{29}$ John Hall, Civil Society, Theori, Histori, Comparasion, (Cambridge : Polity Press, 1995),h. 23.

${ }^{30}$ Walter Lippman, The Good Society, (tp, tt, 1937), h. 59.

${ }^{31}$ Robert H. Thoules, An Introduction to the Psychology of Religion, (London : Cambridge University Press, 1972), h. 71.
} 
manusia dikenalkan dengan pesawat terbang dan teori epistimologi.

Juga teori sosial empirismenya John Lock dan David Hume yang muncul sekitar tahun 1600 - 1700 an dengan melalui indra dan pengalaman manusia dapat memahami kebutuhan hidup dan bersosial, teori sosial kritisisme, yang kemudian muncul positivisme-nya August Comte dengan konsep rasio murni dan pertimbangan yang dimunculkan sekitar tahun 1700 - 1800 an, teori sosial Plato dengan metavisika-nya mampu memunculkan satu teori dan konsep sosial tentang ketertiban.

Hal lain juga teori sosial materialisme dan naturalismenya Demokritos dan Engels yang kemudian memunculkan teorinya Karl Mark dengan dascapital-nya yang dialektik yang kemudian menjadi ideologi rusia dan soviet sebelum masa keruntuhanya, serta pragmatisme yang dimunculkan oleh William James dan John Dhiwey yang menciptakan teori praktis dalam berbuat dan bertindak yang kemudian muncul konsep nalar dan rasa.

Hingga pada fase dan masa lain muncul teori dan metodologi baru Ide open society Pater Francesco Lugano yang memiliki sifat interaksionalisme empiris sebagai kepentingan hidup yang asasi serta hakiki.

\section{Fungsi Teori dalam Sekapur Sirih Ide Open Society}

Dari sekian banyak teori ternyata masih banyak lagi sederetan teori yang digunakan untuk menjadi dasar dalam proses selanjutnya dalam kerangka metodologi terapan open society yang diantaranya metodologinya Martin Heidegger tentang fenomenologi dan rasional serta metodologinya Dadle Shaper yang menelurkan metodologi eksistensial dan Idealisasi yang keempat.

Semuanya yang tersebut diatas terbingkai dalam teori sosial positifisme, rasionalisme dan realisme yang kemudian juga masih banyak lagi munculnya kembali konsep dan teori sosial yang baru dalam wacana kekinian melalui realitas empirik sosial dan budaya.

Lantas, dalam pokok kajian lebih jauh akan memusat perhatian secara serius terutama pada kajian penggalian 
connection theory sikap keagamaan dan sosial. Serta selanjutnya pada hubungan antar agama dan struktur sosial yang terbingkai dalam bahasan ide open society Pater Francesco Lugano yang termasuk kategori alone foreign of immigrant dari Italia dan bertempat tinggal diwilayah Indonesia tepatnya di kabupaten Tulungagung dan Trenggalek yang mayoritas masyarakatnya muslim.

\section{Daftar Pustaka}

Agus Maulana, George Soros, Soros tentang soros, Jakarta: Professional Book, 1997

Andrew M. Greeley, Sociology and Religion, A Collection of Readings, New York: Univercity of Chicago, 1995.

E. Sumaryono, Hermeneutik, sebuah metode Filsafat, Ed. Revisi, Jogjakarta : Kanisius, 1999.

Francis Wahono Nitiprawiro, Teologi Pembebasan, Sejarah, Metode, Praksis, dan Isinya, Jogjakarta: LkiS, 2000

Henry Bergson, Two Sources of Morality and Religion, Inggris; tp. 1935.

J. Milton Yinger, The Scientific Study of Religion, New York: Macmillan Publishing, 1970.

Jacques Waardenburgh, The dialogical dialogue, The worldreligious traditions, current perpectives in religious studies, essays in honour of wilfred cantwell smith, Edinburh: T\&T Clarak Ltd, 1984.

John Hall, Civil Society, Theori, Histori, Comparasion, Cambridge: Polity Press, 1995

Karl R. Popper, The Open Society and Its Enemies, New Jersey: Princeton Univercity Press, 1950

M. Eliade dan Joseph M. Kitagawa, The History of Religions, Essays on Metodology, Chicago: Univercity of Chicago Press, 1974.

M.Munandar Sulaiman, Ilmu Sosial Dasar, Teori dan Konsep Ilmu Sosial, Ed. Revisi, Bandung: Refika Aditama, 1998

Mercia Eliade yang berjudul The history of Religions (Essays in Methodology), Chicago: The Univercity of Chicago Press, 1974. 
Ninian Smart, The Science of Religion and the Sociology of The Knowledge, Princeton: Princeton Univercity Press, 1973.

Noeng Muhajir, Metodologi Penelitian Kualitatif, Ed. III Jogjakarta: Rake Sarasin,1996.

Nur Akhmad, Pluralitas Agama, Kerukunan dalam keragaman, Jakarta: Kompas, 2001.

Robert H. Thoules, An Introduction to the Psychology of Religion, London: Cambridge University Press, 1972

Walter Lippman, The Good Society, tp, tt, 1937. 